\title{
The Acts and the Acts - Some Notes on the Book of Acts in the Second Century
}

\author{
By A. F. Walls
}

'The FORMer treatise I made, O Theophilus, concerning all that Jesus began to do and to teach.' It is a copy-book example of a $\mu \varepsilon^{\prime} v$ clause: the difficulty is, as the world knows, that Luke has declined to put in the corresponding $\delta \varepsilon$ clause, and thus denies us any statement of what he is setting out to do. And so begins the long, long trail in quest of the purpose of Acts.

One thing has clearly emerged from it so far: that the book of Acts is like nothing else on earth. We can find parallels between parts of it and a dozen different types of pagan literature-was not form criticism sent on its way rejoicing when Norden pointed out the parallels between the escape stories therein and some in secular literature?-but it is hard to point to any precise formal parallel, Christian or pagan. There are, indeed, some indications that second century Christians were fully as mystified as Foakes Jackson, and far more mystified than Dibelius, when faced with the question of the purpose of Acts.

It need hardly be mentioned that we do not know whether Luke

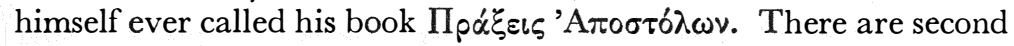
century authorities-the anti-Marcionite prologue to Luke, for instance, and the Muratorian Fragment-which use the title. Now at least two other types of literature called $\Pi_{\rho} \dot{\alpha} \xi \varepsilon เ \zeta$ or Acta were circulating in the second century. They dealt with similar material, and from some points of view one might describe them as pagan and Christian versions of the same literary type! 1

The Christian version is the martyrology. The earliest clear example, so far as I know, is still the Martyrium Polycarpi: basically a mid-second century document, even if von Campenhausen is right in detecting much more substantial elaborations than were formerly allowed for. It is written in the name of a church, and addressed to churches; it describes the progress of an anti-Christian pogrom arising from an excited crowd with the blood-lust up, the witch-hunt for Polycarp, his initial flight, and then his surrender,

I. I admit, of course, that it is as hard to say whether the second century writers called them $\Pi_{p} \alpha \xi \varepsilon\llcorner s$ as it is to say whether Luke called his own so. 
arrest, confrontation with the proconsul, and, in detail, his martyrdom. If the admitted accretions are removed, the story is marked by a moving simplicity and a certain restraint. Not dissimilar in this is the letter of the Gallican churches a couple of decades later: again a letter from a church to a church, describing in detail an anti-Christian outburst and the constancy of Christians who suffered in it.

Somewhat different is what we may call the 'process' type, of which the Passion of Justin and the Acts of the Scillitan martyrs are representative. The letter form is abandoned, and the work purports to give a factual account of the proceedings against conconvicted Christians. The centre is a dialogue between prisoner and judge: there are short, staccato sentences, which could easily reflect a shorthand account made at the time, or an account written up from the official commentarius afterwards.

In both classes, interest is focussed on the last crisis: the trial or the martyrdom, or both. Circulating in time of persecution as an aid to constancy and devotion, they were valued in time of peace as a glorification of the martyrs. And as the cult of the martyrs (which had both Jewish and pagan antecedents) developed, so the martyrology grew in honour, and, incidentally, in elaborate and often grotesque detail. The whole point is to illustrate what Wesley afterwards put into the sentence, 'Our people die well'.

The papyri have revealed that there was a pagan form of this literature, known usually nowadays as the Acta Alexandrinorum (since all the extant examples are from Alexandria), or The Acts of the Pagan Martyrs. All are products of Egyptian nationalism: a species of anti-government propaganda, glorifying the patriots who told the Emperor where to get off, and paid the consequences. The literature must have been dynamite to handle, and been passed between reliable persons in secret. We are better off than our fathers in having them now between two covers, in Fr. Musurillo's meticulous edition.

Within them can be discerned, I think, the same two classes as we have noted in the earlier Christian martyrologies: the 'novelistic' type (I do not mean to imply that the details are necessarily fictitious, but the material has been handled for literary effect), and the 'process' type, centring on a straight-forward dialogue, which may, like its Christian counterpart, derive more or less directly from the official commentarii. Of the former sort one might cite O.P. 1089, which reads like an early John Buchan, and of the latter, O.P. 33 . 
It may even be worthwhile comparing a short section of the Acts of the Scillitan Martyrs with part of the latter, its contemporary.

'Speratus said: We have never done harm to any, we have never lent ourselves to wickedness; we have never spoken ill of any, but have given thanks when ill-treated, because we hold our Emperor in honour.

The Proconsul: We also are religious, and our religion is simple: we swear by the genius of our Lord the Emperor and pray for his safety, as you ought also to do.

Speratus: If you will give me a quiet hearing, I will tell you the mystery of simplicity.

Saturninus: If you begin to speak evil of our sacred rites, I will give you no hearing: but swear rather by the genius of our Lord the Emperor.

Speratus: I do not recognise the Empire of this world; but rather I serve that God, whom no man has seen nor can see. I have not stolen, but if I buy anything, I pay the tax, because I recognise my Lord, the King of kings and the Emperor of all peoples.'

And now O.P. 33 :

'The Emperor recalled Appianus and said: Now do you not know whom you are addressing?

Appianus: I know very well; I am addressing a tyrant.

The Emperor: No, a king.

Appianus: Say not so! The deified Antoninus, your father, deserved imperial power. Listen: in the first place, he was a lover of wisdom, secondly he was no lover of gain, thirdly he was a lover of virtue. You have the opposite qualities; you are a tyrant, a hater of virtue, and a boor.

Caesar ordered him to be led away. (Appianus asks for, and obtains, leave to wear his insignia of rank on the way to execution, uses them for a patriotic demonstration as an Alexandrian gentleman, and is recalled.)

The Emperor: We too are accustomed to bring to their senses those who are mad or beside themselves. You speak only so long as I allow you to speak.

Appianus: I swear by my prosperity, I am neither mad nor beside myself, but I appeal on behalf of my nobility and my rights . . . because I am a noble and a gymnasiarch.

The Emperor: Do you mean that we are ignoble? ...

Appianus: As to that, if you are really ignorant, I will instruct you. In the first place Caesar saved Cleopatra's life when he conquered her kingdom, and, as some say. ...' 
Here the papyrus breaks off, and we never hear what some saythough it does not require much imagination. However, for the present, let us notice that the pagan, like the Christian Acts, fix their interest on the last crisis: what the hero said and did in the events which led to his martyrdom. The purpose is presumably to arouse admiration of the hero, and indignation at the oppressor. Perhaps one other curious parallel might be mentioned in passing. The Acta Alexandrinorum persistently vilify the Jews-so much so that it was once thought that the aim of the literature was essentially antiSemitic. In the earliest Christian martyrology, the Martyrium Polycarpi, we get the eloquently bitter comment that the Jews were noticably active in preparing Polycarp's destruction-'as is their wont'. It is a theme found in other Christian literature about the martyrdoms.

The second century, then, had such $\Pi p \alpha \dot{\xi} \xi \varepsilon \zeta$ as these: and, of course, the Acts of the Apostles is quite unlike any of them. It has trial scenes, but the tendency usually is to acquittal, not to condemnation, interest attaches to long speeches by Stephen and Paul, and only very occasionally to dialogue between prisoner and judge. Two martyrdoms are mentioned, but only slightly, almost incidentally, and in the end, Peter goes to 'his place', and Paul is left in his own hired house, no man forbidding him. This was not enough for men of the second century. If Polycarp and Justin had accounts of their glorious deaths, how much more should Peter and Paul. To this extent, the Acts of the Apostles fell short of what

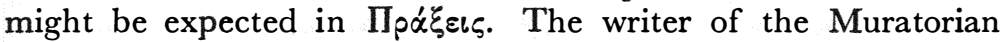
Fragment is embarrassed by this, and finds it necessary to explain that 'Luke has included for good Theophilus the things which were done in his presence, as the omission of Peter's passion clearly shows, and the departure of Paul from Rome on his way to Spain.' That is the point: Peter's martyrdom should have been in, but Luke happened not to be there at the time. But meanwhile the cult of the martyrs had grown, and, as we see in the Quartodeciman and Montanist controversies, the possession of the graves of the apostles had become a matter of importance. Naturally, the need for an account of the last crises of the apostles was widely felt. If Luke was not there, someone else must have been. And so the second century Martyrdom of Peter and Martyrdom of Paul take shape, and become incorporated in the Acts of Peter and the Acts of Paul.

The martyrdoms form only a part of these works: a detachable part, which, as the manuscript tradition shows, was frequently detached. There is little to suggest, however, that they were originally composed independently of the Acts of which they form a 
part. If the martyrdoms are given in such detail to repair what seemed to be a deficiency in the canonical Acts, the rest of these apocryphal Acts take their form because of the canonical book.

But this is to run ahead. What may be particularly notice at this point is the vital significance of the Acts of the Apostles for the second and third century doctrine of catholicity. In rather perverted fashion this has been done by John Knox in his provocative Marcion and the New Testament. This book has not met a tumultuous welcome, but though the thesis has much of romance, it is not all lunacy. We have to remember the development of the doctrine of apostolicity in the second century. The apostles, as the Lord's accredited representatives, had provided the normative interpretation of Christ. When living, they had guided and governed the Church; now they were dead, apostolic tradition must guide it still. But already by the mid-second century several controversies had shown that apostolic tradition was not so simple a matter as it sounded. In the first place, it had become fashionable in Gnostic circles to claim the authority of an apostle for some special train of esoteric teaching outside Scripture. The Gospel of Thomas reflects this habit: Thomas is the supreme adept, the trustee of a fund of understanding beyond the reach of commonplace apostles like Peter and Matthew. In Gnostic thought, apostolic free enterprise was an article of faith.

The second complication arose in quite orthodox circles. Though quite willing to recognize that the apostolate was a planned economy, many local patriots claimed, rightly or wrongly, that particular apostles associated with their own areas had followed or sanctioned particular customs, and if these conflicted-the classic instance is, of course, the Quartodeciman controversy-one might have the inconvenience of one apostle's tradition pitted against another's.

Third, and most important of all, was the influence of that hyperPaulinist Marcion. Here was a man who claimed that only one of the sogennante apostles understood Jesus at all: only one great theologian had rescued the gospel from its Jewish shroud, the Church from the idolatry of the Demiurge. The normative writings for the Church were those of Paul: whether directly, like the epistles, or indirectly, like Luke's Gospel.

It was easy, superficially at least, to divide the New Testament thus between Paul and the rest: all except for one book: Acts. This was the most vulnerable point in Marcion's canonical body: for I take it that Knox's thesis that Acts only appeared at this time will not hold water. Marcion accepted Luke, and Acts was written by Luke: yet this book shows Paul working happily with the Jerusalem 
apostles, and preaching from the Old Testament like any of them. Such things in the epistles could be manipulated out of the text: in the Acts they belonged too much to the structure for the scalpel to a vail.

This aspect of the Acts of the Apostles probably appealed most readily to mid and late second century writers. Acts was a catholic work: it represented the founding of the Church Universal, of which all the apostles, not just one or two, were the pioneers. The Spirit divided His gifts as He would: but what the Lord's servants performed by the Spirit in one place was recognised and ratified by His other servants in another place. Here was Paul, born within the straitest sect of the Jewish religion, operating within the framework of a Church which was big enough to include Peter and James also.

Tertullian treats of this at length in De Praescriptione chapters 22 - 23. He has to combat assertions of stupidity, ignorance and misunderstanding on the part of Peter and the Twelve. His main attacking weapon is Acts, and he tells his opponents that if they will not accept this book, they have no way of showing who their Paul was-nor, indeed, any way of knowing that the Spirit has been given or the Church born.

In similar vein the Muratorian Fragment speaks of 'the Acts of all the Apostles'. The phrase is significant. The Gnostics, with their secret tradition from the apostles, Marcion and his Pauline monomania, the excitable synods with their insistence they they and their grandfathers were only doing what John and Philip had done, are at once rebuked. The Acts is the Acts of all the apostles, the prototype of the Church catholic.

I have argued elsewhere that the Didascalia and the Apostolic Tradition of Hippolytus reflect the influential early third century views of apostolic tradition: that apostolic tradition is not the peculiar tradition of Peter, Philip or John written down, Papias fashion, but the apostolic consensus. If this is correct, it adds interest to the way in which the Didascalia uses the Acts. The book comes from Syria, where there was always a Judaizing tendency, and it is directed against a 'Back to the Torah' movement. Its final sections include an imaginative reconstruction of the Apostolic Council, but made larger than life, after which the apostles-all of them-retire to write 'this catholic Didascalia'. One might almost say that for second century men catholicity, and thus orthodoxy, depends on whether one looks to an apostle, or to all the apostles.

The influence of the Acts of the Apostles on that much-abused collection of Sunday stories, the apocryphal acts, has already been mentioned. When the unregenerate Henry Martyn set about reading 
his Bible, he began with the Acts of the Apostles as likely to prove 'the most amusing'; and the greatest tribute to this sort of influence is that the best Christian novels of the second century-including, no doubt, that grandfather-story behind the pseudo-Clementines-take their cue from the canonical Acts.

Perhaps New Testament scholars have been a trifle hard on these pioneers of the Christian paperback. They wrote much rubbish-and many pious novels since then have been equally banal. They are frequently in atrocious taste, dubious in doctrine or morals, and sometimes frankly heretical. But they knew their market, and we ought to take that factor, at least, seriously. Lucian of Samosata has now appeared in the sober brown duffle coat of a Penguin Classic (it is a wonder that some less reputable publisher has not put him into a sleazy cover for the railway bookstalls). He was in the paperback equivalent in his own day, and, man of the second century that he is, he gives us a glimpse of the sort of world for which the Christian novelists wrote, and an inkling of what pagan erotic romances could be like. If the Acts of Paul praises celibacy a thought too highly, there are Evangelicals in decorous society who have found the monitory stories of the Band of Hope Union a shade legalistic.

What is often overlooked is that these Acts, in their own modest way, sometimes carry a banner against heresy. The bad repute of the author of the Leucian Acts of John has needlessly overlaid his colleagues. The author of the Acts of Paul was, we know, a presbyter in good standing before he wrote his book and got unfrocked for it; and one part of his book, the additional correspondence with the Corinthians, is vigorously and deliberately anti-Gnostic. And though there are many worrying things in the Acts of Peter, they are the rudiments of well-meaning, devotional, popular docetism, not of coherent Gnostic rationalism. Cruder Gnostic forms the book eschews, and Simon explicitly, Marcion implicitly, it repudiates.

Both these works are continuations of the Acts of the Apostles, and assume it. The author of the Acts of Paul has been accused of taking liberties with the canonical Acts, on the assumption that his scheme is meant to run parallel to it; but it may make quite good sense if the Asian journeys described therein are regarded as subsequent to Acts 28 . It is not without interest that most of the personal names which have any parallel with the New Testament occur in the Pastoral Epistles.

If the Acts of Paul are the Sunday Express, a trifle strident, but wearing the robe of respectability, the Acts of Peter are frankly the 
Sunday Pictorial. But justice must be done even to the Sunday Pictorial. Acts of Peter is one of our vigorous second century witnesses for the connection of both Peter and Paul at Rome, and the priority there of Paul. And there is no doubt that its source for this is the Acts of the Apostles. Acts of Peter is, in its own curious way, enunciating the unity of the apostolate, the catholicity of the Church, and, like more respectable authorities, finding its inspiration in Acts of the Apostles. When it puts Simon Magus to flight (and again the origin of the motif is in Acts, however many turns and twists it may have taken on the way), it calls Marcion to his doom.

The stories about Simon have an interesting feature. One of the causes of the apostasy is said to be the cunning use of stories of the Lord's ministry derogatory to Peter, including an agraphon 'They that are with me have not understood me'. Perhaps form-critical methods, so long applied to the Acts of the Apostles, where we have so few comparative materials, could profitably be applied to the Apocryphal Acts, where we have a fair amount. Surely the Sitz im Leben of this story is the very same controversy as that in which Tertullian is engaged in the passage of the De Praescriptione already mentioned. Heretical apologetic made play with stories and sayings, either from the Gospels taken out of context, or from other sources, which reflected discredit on the Jerusalem apostles. To such reports the Acts of Peter makes the same reply as the mighty Tertullianthe essential unity of Peter and Paul. And both use the same proof: the Acts of the Apostles.

Acts, then, as Knox has argued, was a book with particular relevance in the day of Marcion. But that is not for a moment to say that it was written only then. This was not the cannon ball specially manufactured to blast Marcion: it was simply the nut which Marcion could not crack. 